\begin{tabular}{|c|c|}
\hline ANGLES & Angles \\
\hline $\begin{array}{l}\text { NEW PERSPEETUEES } \\
\text { ANGLOPHONE WDRLD }\end{array}$ & New Perspectives on the Anglophone World \\
\hline & $\begin{array}{l}7 \mid 2018 \\
\text { Digital Subjectivities }\end{array}$ \\
\hline
\end{tabular}

\title{
Video introduction to issue 7
}

\section{Claire Larsonneur}

\section{(2) OpenEdition \\ Journals}

Electronic version

URL: https://journals.openedition.org/angles/703

DOI: 10.4000/angles.703

ISSN: 2274-2042

\section{Publisher}

Société des Anglicistes de l'Enseignement Supérieur

\section{Electronic reference}

Claire Larsonneur, "Video introduction to issue 7", Angles [Online], 7 | 2018, Online since 01 November 2018, connection on 07 June 2022. URL: http://journals.openedition.org/angles/703 ; DOI: https:// doi.org/10.4000/angles.703

This text was automatically generated on 7 June 2022.

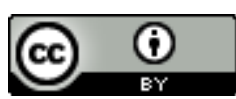

Angles est mise à disposition selon les termes de la Licence Creative Commons Attribution 4.0 International. 


\title{
Video introduction to issue 7
}

\author{
Claire Larsonneur
}

This media file cannot be displayed. Please refer to the online document http:// journals.openedition.org/angles/703

\section{Transcript:}

Welcome to the $7^{\text {th }}$ issue of Angles on digital subjectivities for which I am guest editor. We chat on the Internet, we post pictures, we date, with shop, pay taxes, read the news, search for information. Upon our death we can even bequeath our Facebook profile to a loved one. The Internet is becoming, as Galloway writes, "a contextual framework for being." It's a place to be ourselves, a platform for our subjective expression. We are now digital subjects.

This issue of Angles will explore the various forms taken by our digital selves: pure humans, AI, VR, robots, avatars, and the questions they raise.

As a preview and a teaser for this edition, a few keywords and matching images.

Our first key word is 'Reversals.' With the digital, our sense of self is turned topsyturvy. For example, a user of online content can become an author of user-generated content, or turn into a pirate, streaming illegal content, and vice-versa, as shown by James Meese in his analysis of copyright law. Or sometimes it's hard to tell difference between the opened body of a surgical patient and the innards of a robot. There's an uncanny feeling to Max Aguilera-Helweg's photographs and this is what Jessica Raggazini investigates.

5 Our second keyword therefore had to be 'Bodies.' With the digital the body still runs the show. We tap, we swipe, click, drag and drop. Our bodies are busy online. Moreover, senses and captors collect our body data to be stored and remediated. That means, for example, that digital artistic performance through code is all about bodies, as shown by Jerome Fletcher. If bodies are involved, then gender issues arise. Our robots and AI, male/female, both, or something else... And what about Alexa, the AR for Amazon: why has she been designed, named and voiced as a woman, soft female, or slick mum? And what about avatars? What's the status of their bodies? If I have sex with an avatar, is 
that for real? Does it count as a crime when avatars commit rape or go for children? That's the focus of June Pham's study of The Nether, a play by Jennifer Haley.

This leads us to the third keyword: 'Trauma.' Trauma keeps cropping up in the digital world. All those images always suppressed and re-emerging. Can we reach in, retrain the minds of traumatized soldiers through VR scenarios? The American military think so. Michael Friedman and Kathrin Friedrich wanted to know more...

7 And what do we do with all these disturbing images? When do our digital dreams turn into nightmares? 'Dream.' The digital is the perfect playground for our fantasies and daydreams. Also, it's also a place to give life to our ideals, to go for our dreams. What about revisiting education, for instance, giving more space and voice to the student? With digital tools, Mariusz Marczak suggests we can focus on interaction instead of content. Acting upon our fantasies offers a perspective... but then should we really, and can we really?

Our fifth and final keyword is 'Framed.' Maybe it all boils down to one tricky question: are we framed by the digital? Think ethics. Online ethics. Think data privacy and data protection. Think legal issues... It's complicated, as the phrase goes. But the really scary part is it can mix. Alexa can buy stuff without you clicking or even knowing she's buying. That's a slippery slope. And when a few major digital corporations control almost all of our activity online, are we still independent subjects?

Let's not conclude. Yet let's try to discuss with Siri and see what happens:

- Hello Siri: what are you?

- I'm just a humble virtual assistant.

- Thank you. Hello Siri: who are you?

- I'm Siri, but I don't like talking about myself.

- Okay. Hello Siri: can you find me stuff about digital subjectivities?

- Here's what I found on the web for stuff about digital subjectivities.

- Hello Siri: do you think you are like a human?

- I really couldn't say.

- Hello Siri: you sure can do many things, but can you feel and think as well?

- If you say so.

\section{ABSTRACTS}

This video introduces the thematic contributions on 'Digital Subjectivities'.

La vidéo présente les contributions thématiques sur "Digital subjectivites" ('le sujet digital').

\section{INDEX}

Keywords: video, digital subjectivity, Artificial Intelligence (AI), technology, robotics, literature, art, copyright

Mots-clés: vidéo, art, sujet digital, Intelligence Artificielle (IA), technologie, robotique, littérature, propriété intellectuelle 


\section{AUTHOR}

\section{CLAIRE LARSONNEUR}

Guest editor of Issue 7. Senior Lecturer, currently working at the EA 1569 TransCrit, Université de Vincennes - Paris 8. Claire Larsonneur does research in Translation studies, English Literature and Digital Humanities. She is currently working on a project on Digital authorship. Contact: claire.larsonneur[at]univ-paris8.fr. 